\title{
Comparison of spontaneous labour with induced labour in nulliparous women using modified WHO partograph
}

\author{
Pramila Yadav*, Menka Verma, Sumedha Harne, Megha Sharma
}

Department of Obstetrics and Gynaecology, Jaipur Golden Hospital, Rohini, New Delhi, India

Received: 13 September 2016

Accepted: 08 October 2016

\section{*Correspondence:}

Dr. Pramila Yadav,

E-mail: drpramila11@gmail.com

Copyright: (c) the author(s), publisher and licensee Medip Academy. This is an open-access article distributed under the terms of the Creative Commons Attribution Non-Commercial License, which permits unrestricted non-commercial use, distribution, and reproduction in any medium, provided the original work is properly cited.

\section{ABSTRACT}

Background: Childbirth is the period from the onset of regular uterine contraction until expulsion of placenta. The process by which this normally occurs is called labour. Induction of labour is the artificial initiation of uterine contraction prior to their spontaneous onset, leading to progressive dilatation and effacement of the cervix and delivery of the baby. Labour induction is indicated where the benefits to either the mother or the fetus outweighs the benefit of continuing pregnancy. The aim and objectives of the study was to study the progress of labour in nulliparous women who are having spontaneous labour and in those with induced labour in terms of augmentation of labour, mode of delivery, neonatal outcome and maternal complication.

Methods: This was a randomized comparative study. The study was conducted in department of Obstetrics and Gynaecology at a tertiary care private centre during time period of May 2014 to May 2015 on 120 pregnant women divided into two groups i.e. A and B consisting of 60 women each. All women were nulliparous and $\geq 37$ weeks of gestation age. Those women who had spontaneous onset of labour and reached $\geq 4 \mathrm{~cm}$ cervical dilatation were included in group A and those who were induced with $25 \mathrm{mcg}$ misoprostol vaginally and reached $\geq 4 \mathrm{~cm}$ of cervical dilatation were included in group B. Progress of labour was monitored by Modified WHO partograph.

Results: The mean duration of labour after $4 \mathrm{~cm}$ of cervical dilation in spontaneous labour onset group was 5.43 hours and in the induced group was 5.41 hours with $\mathrm{p}$ value 0.865 , which was statistically not significant. In spontaneous labour onset group, $39.3 \%$ of patients required augmentation of labour with oxytocin compared to $69 \%$ of induced group ( $\mathrm{p}$ value-0.001). More women had vaginal delivery in spontaneous onset labour group (73.3\%) comparative to induced group $(53.3 \%)$ with pvalue-0.023. There was less caesarean section among those in spontaneous labour than induced labour $(20 \%$ versus $41.7 \%)(\mathrm{p}=0.010)$. While most women of induced labour cases reached or crossed action line compared to spontaneous labour $(35 \%$ versus $16.7 \%) \mathrm{p}=0.022$, there were more cases in spontaneous labour moving between alert and action line $(23.3 \%$ versus $10 \%) \mathrm{p}=0.049$.Neonatal outcome and maternal complications were similar in both the group .

Conclusions: We conclude from this study that requirement of augmentation for progress of labour was more in induced group, rate of caesarean section was also high but it does not adversely affect the neonatal outcome and maternal complication if labour is monitored with Modified WHO partograph.

Keywords: Augmentation of labour, Induced labour, Neonatal outcome, Partograph

\section{INTRODUCTION}

Childbirth is the period from the onset of regular uterine contraction until expulsion of placenta. The process by which this normally occurs is called labour. ${ }^{1}$ WHO defines normal birth as: spontaneous in onset, low risk at the start of labour and remaining so throughout labour and delivery. The infant is born spontaneously in the vertex position between 37 to 42 completed weeks of pregnancy, and mother and infant are in good condition after birth. ${ }^{2}$

To be successful, induction of labour must fulfil three aims. First: it should result in labour namely adequate 
uterine contractions and progressive dilatation of cervix. Second: this labour should result in vaginal delivery, as there is little purpose in bringing about labour as a mere preparation for caesarean section. Third: in viable pregnancies, these aims must be achieved with minimum discomfort and risk to both mother and foetus.

The first WHO partograph or 'Composite partograph', covers a latent phase of labour of up to 8 hours and an active phase beginning when the cervical dilatation reaches $3 \mathrm{~cm}$. The active phase is provided with an alert line and an action line, drawn 4 hours apart on the partograph as aids to monitoring labour. This partograph is based on the principle that during active labour, the rate of cervical dilation should not be slower than 1 $\mathrm{cm} /$ hour. A lag time of 4 hours between slowing of labour and the need for intervention is unlikely to compromise the foetus or the mother and avoids unnecessary intervention.

Moreover, differentiating the latent phase from false labour being difficult, diagnosis is often made in retrospect. $^{3}$ To alleviate these disadvantages, a WHO 'Modified Partograph' was introduced by removing the latent phase and considering the beginning of active phase at $4 \mathrm{~cm}$ dilatation of cervix instead of $3 \mathrm{~cm}$. There were some other minor changes which include considering two squares in 1 hour instead of one square in 1 hour in cervical dilatation curve. ${ }^{4}$

WHO further modified the partograph for the third time, this time for used by skilled attendants in health centre. This simplified partograph is colour coded. The area to the left of the alert line in the cervicograph is coloured green, representing normal progress. The area to the right of the action line is coloured red indicating dangerously slow progress in labour. The area in between the alert and action line is coloured amber, indicating the need for greater vigilance. $^{5}$

The aim and objectives of the study was to study the progress of labour in nulliparous women who are having spontaneous labour and in those with induced labour in terms of augmentation of labour, mode of delivery, neonatal outcome and maternal complication.

\section{METHODS}

A randomized comparative study was conducted from May 2014 to May 2015.

The primary variable tested was induction-delivery. With reference to previous studies, a $15 \%$ difference in induction-delivery interval between any of two groups for a type 1error 0.05 and a power of $80 \%$. A sample size of 120 was calculated to detect a significant difference.

The study was conducted in pregnant nulliparous women coming at term in active phase of Labour (with cervical dilatation at least $4 \mathrm{~cm}$ ) either spontaneous or induced with $25 \mathrm{mcg}$ vaginal misoprostol. The study population was divided into two equal groups:

- Labour induced with vaginal prostaglandin (misoprostol) and who reached $\geq 4 \mathrm{~cm}$ dilation.

- $\quad$ Spontaneous onset of labour, who reached $\geq 4 \mathrm{~cm}$ dilatation.

The study received approval from the institutional ethics committee and all participants gave written informed consent. A computer generated randomized list was prepared to enrol the participants in the study.

\section{Inclusion criteria}

- Pregnant nulliparous Women

- Live foetus

- Singleton pregnancy

- Vertex presenting pregnancy

- Gestational Age $\geq 37$ weeks

- Active phase of labour with cervical dilation at least $4 \mathrm{~cm}$

- Either spontaneous or induced

Patient who had spontaneous onset of labour and reached $\geq 4 \mathrm{~cm}$ of cervical dilation were included in group A and patient who were induced with $25 \mathrm{mcg}$ misoprostol and reached $\geq 4 \mathrm{~cm}$ were included in group $\mathrm{B}$, and progress of labour was monitored by modified WHO partograph. Foetal heart rate was recorded half hourly. The state of membrane "I" if membranes are intact, "C" if membranes were ruptured and liquor clear, "M" if membranes were ruptured and liquor meconium stained. Moulding of head at initial examination and subsequent vaginal examination was noted and scoring was done as + or ++ . The most important measures of progress in labour, the rate of dilatation of the cervix and the rate of descent of the foetal presenting part, were recorded by plotting the cervical dilation on the vertical line on the left hand side of the graph in centimetres from 4 to $10 \mathrm{~cm}$.

\section{RESULTS}

The present study was conducted in department of obstetrics and gynecology at a private tertiary care institute of New Delhi on 120 women. Table 1 shows the general characteristics among study participants which were comparable in terms of age, weight, height and BMI.

The above table shows the requirement of augmentation of labour in groups A and B. We observed that 22 $(36.7 \%)$ out of 60 women in group A required augmentation with oxytocin for progress of labour as compared to $40(66.7 \%)$ out of 60 women in group B with $\mathrm{p}$ value 0.001 which was statistically significant.

It was observed that $10(16.7 \%)$ out of 60 women in group A had reached or crossed action line as compared to $21(35 \%)$ out of 60 women in group B with p value of 0.022 which was statistically significant. 
Table 1: General characteristics of study participants.

\begin{tabular}{|lll|l|}
\hline Variables & $\begin{array}{l}\text { Group A } \\
(\mathbf{n = 6 0 )}\end{array}$ & $\begin{array}{l}\text { Group B } \\
(\mathbf{n = 6 0})\end{array}$ & P value \\
\hline Age (years) & $27.17 \pm 1.14$ & $26.95 \pm 1.1$ & 0.290 \\
\hline Weight (kgs) & $60.6 \pm 3.03$ & $61 \pm 2.19$ & 0.409 \\
\hline Height (cms) & $156.74 \pm 2.13$ & $156.44 \pm 1.71$ & 0.400 \\
\hline BMI & $24.67 \pm 1.19$ & $24.93 \pm 0.98$ & 0.194 \\
\hline GA (weeks) & $39.32 \pm .91$ & $39.63 \pm 1.07$ & 0.084 \\
\hline $\begin{array}{l}\text { Cervical } \\
\text { dilatation }\end{array}$ & $4.48 \pm 0.65$ & $4.4 \pm 0.62$ & 0.473 \\
\hline $\begin{array}{l}\text { Descent of } \\
\text { head }\end{array}$ & $3.33 \pm 0.48$ & $3.2 \pm 0.44$ & 0.115 \\
\hline
\end{tabular}

Table 2: Augmentation of labour with oxytocin.

\begin{tabular}{|llll|}
\cline { 1 - 3 } Augmentation & $\begin{array}{l}\text { Group A } \\
(\mathbf{n = 6 0 )}\end{array}$ & $\begin{array}{l}\text { Group B } \\
(\mathbf{n}=60)\end{array}$ & $\begin{array}{l}\text { P } \\
\text { value }\end{array}$ \\
\cline { 1 - 3 } Yes & $22(36.7 \%)$ & $40(66.7 \%)$ & \multirow{2}{*}{0.001} \\
\cline { 1 - 3 } No & $38(63.3 \%)$ & $20(33.3 \%)$ & \\
\hline
\end{tabular}

Table 3: Cervicograph reaching or crossing Action line.

\begin{tabular}{|llll|} 
Cervicograph & $\begin{array}{l}\text { Group A } \\
(\mathrm{n}=60)\end{array}$ & $\begin{array}{l}\text { Group B } \\
(\mathrm{n}=60)\end{array}$ & $\begin{array}{l}\text { P } \\
\text { value }\end{array}$ \\
\cline { 1 - 2 } $\begin{array}{l}\text { Reaching/crossing } \\
\text { action line }\end{array}$ & $10(16.7 \%)$ & $21(35 \%)$ & \multirow{2}{*}{0.001} \\
\cline { 1 - 2 } None & $50(83.3 \%)$ & $39(65 \%)$ & \\
\hline
\end{tabular}

Table 4: Mode of delivery.

\begin{tabular}{|lll|l|}
\hline $\begin{array}{l}\text { Mode of } \\
\text { delivery }\end{array}$ & $\begin{array}{l}\text { Group A } \\
(\mathrm{n}=60)\end{array}$ & $\begin{array}{l}\text { Group B } \\
(\mathrm{n}=60)\end{array}$ & $\begin{array}{l}\text { P } \\
\text { value }\end{array}$ \\
\hline Vaginal delivery & $44(73.3 \%)$ & $32(53.3 \%)$ & 0.023 \\
\hline Caesarean section & $12(20 \%)$ & $25(41.7 \%)$ & 0.010 \\
\hline Instrumental VD & $04(6.7 \%)$ & $03(5 \%)$ & 0.997 \\
\hline
\end{tabular}

Table 5: Neonatal outcome.

\begin{tabular}{|lll|l|}
\hline Parameters & $\begin{array}{l}\text { Group A } \\
(\mathbf{n = 6 0 )}\end{array}$ & $\begin{array}{l}\text { Group B } \\
(\mathbf{n}=60)\end{array}$ & $\begin{array}{l}\text { P } \\
\text { value }\end{array}$ \\
\hline Birth weight & $3 \pm .19$ & $2.98 \pm 0.2$ & 0.621 \\
\hline $\begin{array}{l}\text { Apgar score at 1 } \\
\text { min }\end{array}$ & $7.1 \pm 1.22$ & $7.17 \pm 1.2$ & 0.763 \\
\hline $\begin{array}{l}\text { Apgar score at 5 } \\
\text { min }\end{array}$ & $9.38 \pm .8$ & $9.33 \pm .8$ & 0.733 \\
\hline
\end{tabular}

Table 2 shows the mode of delivery. There was an increased vaginal delivery in group A whereas caesarean section was increased in group B. This was statistically significant.

Table 4 shows the mode of delivery. There was an increased vaginal delivery in group A whereas caesarean section was increased in group B. This was statistically significant.
Table 6: Maternal outcome.

\begin{tabular}{|llll|}
\hline Complication & $\begin{array}{l}\text { Group A } \\
(\mathbf{n = 6 0 )}\end{array}$ & $\begin{array}{l}\text { Group B } \\
(\mathbf{n}=60)\end{array}$ & $\begin{array}{l}\text { P } \\
\text { value }\end{array}$ \\
\hline No & $57(95 \%)$ & $53(88.3 \%)$ & 0.19 \\
\hline Perineal tear & $2(3.3 \%)$ & $1(1.7 \%)$ & 1.00 \\
\hline PPH & $1(1.7 \%)$ & $4(6.7 \%)$ & 0.36 \\
\hline Tachysystole & $0(0 \%)$ & $1(1.7 \%)$ & 1.00 \\
\hline Cervical tear & $0(0 \%)$ & $1(1.7 \%)$ & 1.00 \\
\hline
\end{tabular}

Table 5 and 6 shows the neonatal and maternal outcome among the two study groups. There was similar occurrence of events in both groups when compared for maternal and neonatal events.

\section{DISCUSSION}

Induction of labour is one of the common interventions in obstetrics and is not without risk. In many circumstances, induction of labour may either result in an increase or a decrease in maternal or perinatal morbidity.

In present study, 40 (66.7\%) women in group B required augmentation of labour with oxytocin as compared to 22 $(36.7 \%)$ women in group A. The difference between two groups was statistically significant $(\mathrm{p}=0.001)$. Similar to our study, Selo-Ojeme D et al conducted a study and they also concluded a higher rate of requirement of augmentation with oxytocin among those who had induced labour and in a study conducted by Alyasin ZT et al, they also found need for oxytocin was significantly increased in the induced group. ${ }^{6,7}$ Hence we concluded that augmentation is needed frequently in induced group compared to spontaneous group, but, keeping in mind that oxytocin is associated with increased risk of abnormal fetal heart pattern, so proper monitoring of labour and dose titration according to uterine contraction is necessary in patients undergoing induced labour.

We found that more women in the induced group reached or crossed action line (35\% versus $16.7 \%$ ) as compared to spontaneous group and this was found statistically significant $(\mathrm{p}=0.022)$. Hence, we concluded that due to timely intervention most of the patient had normal active phase Our study was comparable to a study done by Orji EO et $\mathrm{al}^{8}$ in which they also found similar results i.e. $55.1 \%$ patients had normal active phase, $27.9 \%$ patients moved between alert and action line and $16.9 \%$ patients reached or crossed action line in spontaneous group while $57.4 \%$ patients had normal active phase $9.6 \%$ patients moved between alert and action line and $33.1 \%$ patients reached or crossed action line in induced group. In another study done by Murlidhar L et al, found that when cervical dilatation was on the left of the alert line, more vaginal deliveries occurred and babies had good APGAR score compared to those, whose cervical dilatation moved between alert and action line or crossed or reached action line. ${ }^{9}$ 
Regarding mode of delivery, spontaneous onset of labour had more vaginal delivery compared to induced labour group while vice versa for caesarean section. Our results were similar to the study done by Orji EO et al, in which they concluded that larger proportion of women in spontaneous group had vaginal delivery compared to induced group and also lesser proportion of caesarean section in spontaneous group. ${ }^{8}$ Alyasin ZT et al, conducted a study and they compared elective labour induction with spontaneous onset of labour in post-dated pregnancy and they concluded that rate of caesarean section was more in induced group. ${ }^{7}$ In a study done by Jankiraman $\mathrm{V}$ et al, they concluded that induced nulliparous had increased rate of caesarean section compared spontaneous onset labour. ${ }^{10}$

Regarding neonatal outcome, both groups had similar events. Orji EO et al conducted a study and they found that induced group had better APGAR at one and five minutes compared to spontaneous group. ${ }^{8}$ A study done by Selo-Ojeme $\mathrm{D}$ et al, in which they concluded that Apgar $<5$ at 5 minutes was more common in induced group compared to spontaneous group. ${ }^{6}$ For maternal complications also, both groups had similar events. Similar to our study Alyasin ZT et al in their study found no significant difference in spontaneous and induced group. ${ }^{7}$ In an another study done by Kudagi LB et al, they compared intra-vaginal misoprostol with intracervical dinoprostone gel for induction of labour and they found that no significant difference in maternal complications in both the groups. ${ }^{11}$

\section{CONCLUSION}

We conclude from this study that requirement of augmentation for progress of labour was more in induced group, rate of caesarean section was also high but it does not adversely affect the neonatal outcome and maternal complication if labour is monitored with Modified WHO partograph.

Funding: No funding sources Conflict of interest: None declared

Ethical approval: The study was approved by the Institutional Ethics Committee

\section{REFERENCES}

1. Cunningham FG, Leveno KJ, Bloom SL, Hauth JC, Rouse DJ, Spong YC. Normal Labor and Delivery; Willim Obstetrics. $23^{\text {rd }}$ Edition. USA. McGraw-Hill. 2010;17:373-87.

2. Donald I. Management of labour, In: Mishra R. Practical obstetric problems, $7^{\text {th }}$ edition, New Delhi. BI publication Pvt Ltd. 2014;24:466-80.

3. Mathai M. The Partograph for the prevention of Obstructed Labour. Clin Obstet Gynecol. 2009;52(2):256-69.

4. Mathews JE, Rajaratnam A, George A, Mathai M. Comparison of two World Health Organization (WHO) partographs. Int J Gynecol. 2007;96(2):14715010 .

5. WHO, UNICEF, UNFPA \& World Bank. Pregnancy, childbirth, Postpartum and Newborn Care; A Guide for Essential Practice. Geneva; WHO; 2006.

6. Selo-Ojeme D, Rogers C, Mohanty A, Zaidi N, Villar R, Shangaris P. Arch Gynecol Obstet. 2011;284(2);337-41.

7. Alyasin ZT, Al-Salami KS, Abd al abbas H. Comparison between elective labour induction and spontaneous onset of labour in prolonged pregnancy. Bas J Surg. March 16, 2010. Available from: http://www.iasj.net/iasj?func=fulltext\&aIId=55178.

8. Orji EO, Olabode TO. Comparative study of labour progress and delivery outcome among induced versus spontaneous labour in nulliparous women using modified WHO partograph. Nepal Journal of Obstetrics and Gynecology. 2008;3(1):24-8.

9. Murlidhar L, Malini KV, Shetty VH. Partographic Analysis of Spontaneous Labour at Term in Primigravida. The journal of Obstetrics and Gynecology of India. 2012;62(6):635-40.

10. Jankiraman V, Ecker J, Kaimal AJ. Comparing the second stage in induced and spontaneous labour. Obstet Gynecol. 2010;116(3):606-11.

11. Kudagi LB, Sailaja L, Kumar PR, Babu SC. A comparative study of intravaginal misoprostol with intracervical dinoprostone gel for induction of labour in pregnancy. Asian J Pharm Clin Res. 2013:6(2):174-8.

Cite this article as: Yadav $\mathrm{P}$, Verma M, Harne $\mathrm{S}$ Sharma M. Comparison of spontaneous labour with induced labour in nulliparous women using modified WHO partograph. Int J Reprod Contracept Obstet Gynecol 2016;5:4005-8. 